\title{
Combined Efficacy of Organic Manures, Bio-Control Agents and Bio-Fertilizers in Improving Growth, Flowering and Quality Parameters of Gladiolus Cv. American Beauty
}

\author{
Khwairakpam Lily Devi*, Soumen Maitra and P. M. Bhattacharya
}

College of Agricultural Engineering and Post Harvest Technology (CAU), Ranipool, East Sikkim - 737135 (Sikkim), India

Department of Floriculture, Medicinal and Aromatic Plants, Faculty of Horticulture, Uttar

Banga Krishi Viswavidyalaya (UBKV), Pundibari, Cooch Behar, West Bengal- 736165, India

*Corresponding author

\section{A B S T R A C T}

Keywords

Gladiolus,

American beauty,

Organic farming,

Vegetative growth,

Flowering

\section{Article Info}

Accepted:

12 September 2019

Available Online:

10 October 2019
The present investigation was carried out to develop the organic farming practices of gladiolus cv. American Beauty utilizing bio-fertilizers and bio-control agents along with organic manures in 16 different combinations and the effects were compared with application of FYM only. The results indicated that growth and flowering as well as quality parameters were significantly influenced by integration of organic manures, biofertilizers and bio-control agents. The tallest plants $(127.19 \mathrm{~cm})$ and maximum number of leaves/ plant (14.04) were observed in the treatment consisting of Vermicompost (0.5 $\mathrm{Kg} / \mathrm{m}^{2}$ ) + Bio-inoculant treated corm + application of Bio-control agents (Pseudomonas fluorescens + Trichoderma @ $0.5 \mathrm{Kg} / \mathrm{m}^{2}$ each) + application of Nitrogenous Bio-fertilizers (Azotobacter + Azospirilum mixture @ $0.5 \mathrm{Kg} / \mathrm{m}^{2}$ each) + application of Phosphatic Biofertilizer (Phosphate solubilizing bacteria @ $0.5 \mathrm{Kg} / \mathrm{m}^{2}$ ) $\left[\mathrm{T}_{15}\right]$. This treatment also recorded earliest spike emergence(60.48 DAP) and superiority in yield attributing characters like spike length $(93.06 \mathrm{~cm})$, number of florets per spike(13.39), vase-life (6.90 days), weight of corm with scale leaf (72.34 g), weight of dehusked corms (70.57 g) and diameter of corms $(69.16 \mathrm{~mm})$. The quality parameters like chlorophyll, total phenol and protein content of leaves as well as anthocyanin content of florets were also influenced by combined use of organic manures and biological sources of nutrients. Hence, $\mathrm{T}_{15}$ may be considered as best supplementation of nutrients through organic approach and may be included in the package of practices for organic production of gladiolus in the Terai region of West Bengal.

\section{Introduction}

Gladiolus (Gladiolus sp.) is one of the most popular bulbous flowering ornamental plants with magnificent inflorescence. It is also known as the "Queen of bulbous flower crops" grown in many parts of the world. It is one of the principal flower crops of Terai 
region of West Bengal. The Terai region possesses unique climatological advantages, which is suitable for gladiolus cultivation for most part of the year (except in rainy season). Successful cultivation of gladiolus from this region often hinders due to some of the inherent problems of the agro-climatic condition as well as corm rot that threaten their economic value. Though the texture of the soil is suitable for production of bulbous plants, low $\mathrm{pH}$ of the soil and the associated problem of phosphorus fixation renders this nutrient element unavailable in most of the areas (Pati and Mukhopadhyay, 2008).

Gladiolus is a heavy feeder and it requires considerable amount of manures and fertilizers to produce quality spikes. The corm rot both in the field and in storage condition is another important problem of gladiolus cultivation. The pathogen may cause as much as $60-80 \%$ damage to gladiolus depending on varietal response (Devi et al., 2017). However, the excessive use of chemical fertilizers/ fungicides to meet its nutritional requirement and/ or to control inherent diseases of corm rot may cause serious damage to the soil productivity and environment degradation (Sharma and Singhvi, 2017). Accumulation of toxic chemicals rendering the soil infertility, nutrient imbalance, ecosystem destruction, affects the yield and quality of the produce in the long run. In that condition, sustainable agricultural practices have become a very important consideration among the commercial growers. To overcome all these problems - a cheaper, better and safer way is necessary in order to improve the soil fertility status and sustainable production system with minimum Eco-hazards. All these criteria can be achieved through application of biofertilizers alternatively known as "microbial inoculants", are carrier-based preparations containing micro-organisms in sufficient numbers when applied as seeds treatment or soil application that accelerate certain microbial process that mobilized the available nutrient elements allowing to assimilate easily by plant also restricts the growth of disease producing organism helping plant growth and yield (Singh et al., 2014). They are widely accepted as low-cost supplements to chemical fertilizers, save $25 \%$ input (Thakur et al., 2016) and have no deleterious effect either on soil health or environment.

Devi et al., (2017) reported the use of chemical fungicides in regular practice in managing the diseases lead to a pollution problem, residual effects, toxicity, development of resistance in pathogen and imbalance in soil microbial associations. Application of bio-control agents is the alternative source to control/reduce the incidence of diseases like corm rot, wilt or yellow diseases and other harmful soil borne pathogen population and also exert the scope as a plant growth promoting rhizobacteria enhancing the plant growth, development and flowering in gladiolus (Sisodia and Singh, 2015). Several experiments were conducted to control this problem chemically and by use of bio-control agents but report on the use of a combination of bio-control agents and biofertilizers along with organic manures is very scanty. Keeping all these in view the present investigation was undertaken to find out the most effective combination in the package of practice for quality production of gladiolus through organic farming in the Terai region of West Bengal.

\section{Materials and Methods}

The experiment was conducted at the instructional farm of the Department of Floriculture, Medicinal and Aromatic plants, Faculty of Horticulture, Uttar Banga Krishi Viswavidyalaya, Pundibari, Cooch Behar during 2010- 2011 and 20112012. CoochBehar is geographically situated in the plains of the Terai zone of West Bengal 
especially in North Bengal at $26^{\circ} \mathrm{N}$ latitude and $89^{\circ} \mathrm{E}$ longitude and at an altitude of $43 \mathrm{~m}$ above the mean sea level. The climate of the region is humid sub-topical with hot summer and cold winter. The average annual rainfall varies from 2000-3000 mm, bulk of which being received during the monsoon (June to September) with a few pre-monsoon showers. The soil of the site of experiment was slightly acidic in nature ( $\mathrm{pH}-5.38)$.

The design of experiment was Randomized Block Design (RBD) consisting of sixteen treatments replicated thrice. The treatments comprising of two types of organic manures [Farm yard manure (FYM) and vermicompost (VC)], two types of bio-control agents (Pseudomonas fluorescens and Trichodermaviride) and three types of biofertilizers (Azotobacter, Azospirilum and Phosphate solubilizing bacteria) with their combinations as given in Table 1.

The biological inoculants collected from the Department of Plant Pathology, Faculty of Agriculture, UBKV were used in five different heaps of the biological inoculants [Trichoderma (Strain UBT-18), Pseudomonas fluorescens (Strain VPF-1), Azotobacter (Strain UBAZ-1), Azospirillum (Strain UBAS1)and Phosphate solubilizing bacteria (Strain UBPS-9)] with vermicompost @ 10g/Kg were prepared seven days before planting. The microbial resource enriched vermicompost was then applied separately from each heap as per the treatment during the planting of corms at the rate of $0.5 \mathrm{~kg}$ mixture $/ \mathrm{m}^{2}$. Uniform size of corms of gladiolus cv. American Beautywere treated with Carbendazim @ $1 \mathrm{~g} /$ lit of water for $1 / 2$ an hour for the treatments $\left(\mathrm{T}_{2}, \mathrm{~T}_{4}, \mathrm{~T}_{6}, \mathrm{~T}_{8}, \mathrm{~T}_{10}, \mathrm{~T}_{12}, \mathrm{~T}_{14}\right.$ and $\left.\mathrm{T}_{16}\right)$ and the remaining other corms (for treatments $\mathrm{T}_{1}, \mathrm{~T}_{3}$, $\mathrm{T}_{5}, \mathrm{~T}_{7}, \mathrm{~T}_{9}, \mathrm{~T}_{11}, \mathrm{~T}_{13}$ and $\mathrm{T}_{15}$ ) were treated with slurry of bio-inoculants prepared with CMC (carboxymethyl cellulose sodium salt) dipped for 5-10 minutes prior to planting. Treated corms were planted inraised beds at the spacing of $30 \mathrm{~cm} \times 30 \mathrm{~cm}$ (9 corms/ bed). All the cultural practices were kept uniform for all the treatments and standard practices were adopted. Observations on growth, flowering and corm production attributes were recorded from five randomly selected plants of each replication. Chlorophyll content of the leaves were done using chlorophyll meter - SPAD 502. The other parameters like protein content was estimated following Lowryet al.,(1951), leaf total phenol content following Malick and Singh (1980) and anthocyanin pigment concentration of floret following Cordenunsi et al., (2003). Data of both the years were pooled and subjected to analysis of variance to determine the differences among group means was done following Ronald Fisher's statistical hypothesis testing technique through MSTATC (Mathematic and Statistic Compiler) software. The critical difference between the treatments was also determined at $5 \%$ level.

\section{Results and Discussion}

The pooled data (Table 2 and 3) reflected that most of the attributes were significantly affected by the combined treatment of organic manures, bio-control agents and bio-fertilizers and the effects were compared with application of only FYM @ $5 \mathrm{Kg} / \mathrm{m}^{2}+$ Chemical corm treatment $\left(\mathrm{T}_{2}\right.$, control) in the field. $\mathrm{T}_{15}$ produced the tallest plants $(74.46$ $\mathrm{cm})$ at 30 days after planting (DAP) and at 60 DAP $(98.79 \mathrm{~cm})$ which was statistically at par with $\mathrm{T}_{16}, \mathrm{~T}_{8}, \mathrm{~T}_{7}, \mathrm{~T}_{14}, \mathrm{~T}_{13}$ (at $30 \mathrm{DAP}$ ) and $\mathrm{T}_{16}$, $\mathrm{T}_{8}, \mathrm{~T}_{7}$ (at $60 \mathrm{DAP}$ ). Whereas at $90 \mathrm{DAP}, \mathrm{T}_{15}$ produced significantly tallest plants (127.19 $\mathrm{cm}$ ) over the rest of treatments. The same treatment $\left(\mathrm{T}_{15}\right)$ also induced maximum number of leaves/ plant at 30 DAP (12.92), 60 DAP (13.87) and at 90 DAP (14.04). Whereas, the lowest plant height $(62.38 \mathrm{~cm}, 76.46 \mathrm{~cm}$ and $97.88 \mathrm{~cm}$ ) and the lowest number of leaves/ plant (9.00, 9.25 and9.38) were 
recorded in $\mathrm{T}_{2}$, respectively at 30,60 and 90 DAP (Table 2). The favourable effect of $\mathrm{T}_{15}$ to produce more vegetative growth might be due to the enhancement in the ability of the plants through application of those biological resources (corm treatment as well as soil application) through better uptake of nutrient elements, solubilisation and mobilisation of insoluble form of phosphorous in the soil, better photosynthetic ability, enhanced sourcesink relationship which facilitated the physiological and biochemical activities at a higher magnitude (Kumar et al., 2011) and antagonistic of bio-control agents to many phytopathogenic fungi against disease incidence as well as plant growth promoting rhizobacteria (Sisodia and Singh, 2015). Besides, the applied organic manures vermicompost possibly supplied the macro and micro ( $\mathrm{Zn}, \mathrm{Cu}, \mathrm{Fe}$, and $\mathrm{Mn}$ ) nutrients, enzymes and growth promoting substances (Kumar et al., 2011) lead to enhanced vegetative growth. Improved physiological and biological activities enhanced biological efficiency of the plant enabling synthesis of maximum metabolites and photosynthates ultimately encouraging quick growth in the form of plant height and leaf production. The effect of microbial resources and organic manure on improved vegetative growth of gladiolus was also reported by Sathyanarayana et al., (2018) at100\% RDF + FYM @ 7.5 t/ha + Azotobacter + PSB + KMB + 1\% foliar spray of Nauroji Novel Organic Liquid Fertilizer application and Pandey et al., (2013) through corm inoculation as well as soil application biocontrol agents + vermicompost.

The earliest (60.48 DAP) spike emergence was noticed in $T_{15}$ which was at par with $T_{16}$, $\mathrm{T}_{8}$ and maximum delay (64.81 DAP) was noticed in $\mathrm{T}_{1}$ (Table 2). Earlier completion of better vegetative growth lead to early flowering is due to improved physiological and biochemical activities as well as rate of photosynthesis in $T_{15}$. PSB induced better uptake of phosphorus as well as micro-nutrient like $\mathrm{Zn}$, a precursor of auxin biosynthesis, might lead to improved vegetative growth, dry matter accumulation, better photosynthetic ability and supply of photosynthates and their partitioning towards the initiation of floral primordia (Dubey et al., 2010). The use of organic manure supplemented biological resources for earlier completion of better vegetative growth as well as early initiation of flower bud was also noticed by Kuotsuet al., (2018) in gladiolus; Srivastava et al., (2014) in tuberose and Kumar et al., (2017) in tomato. Similar results in early flowering and floret opening in gladiolus (Sisodia and Singh, 2015) through application of Trichoderma along with vermicompost probable reason may be effective control of diseases and its opportunistic role to enhance plant growth. Similarly, $\mathrm{T}_{15}$ was found as the most improved performer with regard to longest $(93.06 \mathrm{~cm})$ spike length, maximum number (13.39) of florets per spike and maximum (6.90 days) of vase-life which were statistically at par with $\mathrm{T}_{16}, \mathrm{~T}_{8}$ and $\mathrm{T}_{7}$ (Table 2). Whereas, $\mathrm{T}_{1}$ recorded the lowest spike length $(69.78 \mathrm{~cm})$, number of florets per spike (8.28) and vase-life (5.06) followed by $\mathrm{T}_{2}$. The quality parameters like spike length, number of florets/ spike and post-harvest life of cut spikes were improved considerably in $T_{15}$ might be due to their effect in facilitating better partitioning of nutrients resulting better nutrition followed by growth promotion along with proper root function favoured better reproductive growth which was reflected through the parameters. The microbial resources and organic manure mediated improvement in spikes quality parameters was also noticed by Sathyanarayana et al., (2017), Pansuriya et al., (2018) and Ali et al., (2014) in gladiolus. Beneficial effect of bio-control agent and vermicompost in improving the quality parameters of spikes in gladiolus has been documented by Pandey et al., (2013). The improved stored food reserves within the spike 
as a result of better nutrition during the vegetative and reproductive phases as well as formation of cytokinin like plant growth substances along with auxin and $\mathrm{GA}_{3}$ influenced higher spike length and better post-harvest life of cut spikes as the antisenescence property of cytokinin is well versed (Srivastava et al., 2014) which was also supplemented through increased carbohydrate reserves within the cut spikes.

The findings of the present experiment in respect of vase life of spikes are also in close proximity of the findings of Pansuriya et al., (2018) and Sathyanarayana et al., (2018) in gladiolus.

Highly significant difference was observed among different treatments in corm quality of gladiolus cv. American Beauty (Table 3). $\mathrm{T}_{15}$ produced the maximum weight of corm with scale leaf $(72.34 \mathrm{~g})$ and weight of dehusked corms $(70.57 \mathrm{~g})$, which were statistically at par with $\mathrm{T}_{16}, \mathrm{~T}_{8}, \mathrm{~T}_{7}, \mathrm{~T}_{14}$ and $\mathrm{T}_{13}$. Whereas $\mathrm{T}_{2}$ was found with minimum weight of corm with scale leaf $(52.21 \mathrm{~g})$ as well as dehusked corms $(50.41 \mathrm{~g})$. Similarly, the maximum diameter of corms $(69.16 \mathrm{~mm})$ was recorded in $\mathrm{T}_{15}$, which was statistically at par with $\mathrm{T}_{16}$, $\mathrm{T}_{8}$ and the minimum diameter of corms $(61.23$ $\mathrm{mm}$ ) was noticed in $\mathrm{T}_{2}$.

The improved weight and sizes of corms in $\mathrm{T}_{15}$ might be due to the integrated effect exerted by the nitrogen fixing microbes to fix higher amount of atmospheric nitrogen at the root zone and to make it available for utilization of the crop; phosphorous solubilizing bacteria to release the phosphorous that helps in better root growth thereby translocation efficiency of phosphorous and other micronutrients resulting increased biosynthesis of chlorophyll to facilitate photosynthesis thereby production and distribution of photosynthates for all round development of the crops. Besides, the bio-control agent that imparted disease resistance to the crop and helped in biosynthesis of growth promoting substances (Sisodia and Singh, 2015) as well as made the rhizosphere healthy for successful growth and the organic manure like vermicompost which were considered as a supplier of nutrient, slowly, throughout the crop growth, development, flowering and post-harvest corm formation period on a continual basis, responsible for supply of macro and micro nutrient elements essential to gladiolus plant.

As a result, plants became able to synthesise more assimilates and after harvesting of flowers which were channelized to the storage organ leading to formation of better quality corms. Similar kind of results was also noticed by Sathyanarayana et al., (2018) in gladiolus and Naznin et al., (2015) in tuberose.

It is also revealed from the data presented in Table 3 that the highest chlorophyll content (67.07 SPAD) of leaves, leaf protein content $(7.20 \mathrm{mg} / \mathrm{g}$ of fresh weight)and floret anthocyanin content $(214.17 \mathrm{mg} / 100 \mathrm{~g}$ of fresh weight) were obtained from $\mathrm{T}_{15}$ which was statistically at par with $\mathrm{T}_{16}, \mathrm{~T}_{8}, \mathrm{~T}_{3}, \mathrm{~T}_{7}, \mathrm{~T}_{14}$, $\mathrm{T}_{13}, \mathrm{~T}_{5}, \mathrm{~T}_{6}$ (in case of leaf chlorophyll content), $\mathrm{T}_{16}, \mathrm{~T}_{8}, \mathrm{~T}_{7}, \mathrm{~T}_{4}$ (in case of leaf protein content) and $\mathrm{T}_{16}, \mathrm{~T}_{7}, \mathrm{~T}_{8}, \mathrm{~T}_{14}, \mathrm{~T}_{13}$ (in case of floret anthocyanin content). The minimum leaf chlorophyll content (61.32 SPAD), leaf protein content $(3.96 \mathrm{mg} / \mathrm{g}$ of fresh weight) and floret anthocyanin content $(176.67 \mathrm{mg} / 100 \mathrm{~g}$ of fresh weight) were found in $\mathrm{T}_{2}$. Also, $\mathrm{T}_{15}$ recorded with highly significant Phenol $(0.96 \mathrm{mg} / \mathrm{g}$ fresh weight $)$ content of leaves over the rest of treatments and lowest phenol content $(0.42 \mathrm{mg} / \mathrm{g}$ fresh weight $)$ was observed in $\mathrm{T}_{2}$.

Nitrogen, the essential part of nucleic acid, was supplied continuously at a steady rate by the manures and microbes together enhancing more vegetative growth. 
Table.1 Treatments combination details

\begin{tabular}{|c|c|}
\hline Notations & Treatment details \\
\hline $\mathrm{T}_{1}$ & FYM $\left(5 \mathrm{Kg} / \mathrm{m}^{2}\right)+$ Bio-inoculant treated corm $(\mathrm{BTC})$ \\
\hline $\mathbf{T}_{2}$ & FYM $\left(5 \mathrm{Kg} / \mathrm{m}^{2}\right)+$ Chemical treated corm $(\mathrm{CTC})$ \\
\hline $\mathbf{T}_{3}$ & $\begin{aligned} \text { FYM }\left(5 \mathrm{Kg} / \mathrm{m}^{2}\right)+\mathrm{BTC} & + \text { Bio-control agent (a mixture of Pseudomonas fluorescens } \\
& + \text { Trichoderma @ } 0.5 \mathrm{Kg} / \mathrm{m}^{2} \text { each) }\end{aligned}$ \\
\hline $\mathbf{T}_{4}$ & FYM $\left(5 \mathrm{Kg} / \mathrm{m}^{2}\right)+\mathrm{CTC}+$ Bio-control agent \\
\hline $\mathbf{T}_{5}$ & $\begin{array}{c}\text { FYM }\left(5 \mathrm{Kg} / \mathrm{m}^{2}\right)+\text { BTC + Bio-control agent + Nitrogenous Bio-fertilizer (a mixture } \\
\text { of Azotobacter + Azospirilum@ } 0.5 \mathrm{Kg} / \mathrm{m}^{2} \text { each) }\end{array}$ \\
\hline $\mathbf{T}_{6}$ & FYM $\left(5 \mathrm{Kg} / \mathrm{m}^{2}\right)+\mathrm{CTC}+$ Bio-control agent + Nitrogenous Bio-fertilizer \\
\hline $\mathbf{T}_{7}$ & $\begin{array}{l}\text { FYM }\left(5 \mathrm{Kg} / \mathrm{m}^{2}\right)+\text { BTC + Bio-control agent + Nitrogenous Bio-fertilizer + } \\
\text { Phosphatic Bio-fertilizer (Phosphate solubilizing bacteria @ } 0.5 \mathrm{Kg} / \mathrm{m}^{2} \text { each) }\end{array}$ \\
\hline $\mathbf{T}_{\mathbf{8}}$ & $\begin{array}{c}\text { FYM }\left(5 \mathrm{Kg} / \mathrm{m}^{2}\right)+\mathrm{CTC}+\text { Bio-control agent }+ \text { Nitrogenous Bio-fertilizer }+ \\
\text { Phosphatic Bio-fertilizer }\end{array}$ \\
\hline $\mathbf{T}_{9}$ & $\mathrm{VC}\left(0.5 \mathrm{Kg} / \mathrm{m}^{2}\right)+\mathrm{BTC}$ \\
\hline $\mathbf{T}_{10}$ & $\mathrm{VC}\left(0.5 \mathrm{Kg} / \mathrm{m}^{2}\right)+\mathrm{CTC}$ \\
\hline $\mathbf{T}_{11}$ & $\mathrm{VC}\left(0.5 \mathrm{Kg} / \mathrm{m}^{2}\right)+\mathrm{BTC}+$ Bio-control agent \\
\hline $\mathbf{T}_{12}$ & $\mathrm{VC}\left(0.5 \mathrm{Kg} / \mathrm{m}^{2}\right)+\mathrm{CTC}+$ Bio-control agent \\
\hline $\mathbf{T}_{13}$ & $\mathrm{VC}\left(0.5 \mathrm{Kg} / \mathrm{m}^{2}\right)+\mathrm{BTC}+\mathrm{Bio}$-control agent + Nitrogenous Bio-fertilizer \\
\hline $\mathbf{T}_{14}$ & $\mathrm{VC}\left(0.5 \mathrm{Kg} / \mathrm{m}^{2}\right)+\mathrm{CTC}+$ Bio-control agent + Nitrogenous Bio-fertilizer \\
\hline $\mathbf{T}_{15}$ & $\begin{array}{c}\mathrm{VC}\left(0.5 \mathrm{Kg} / \mathrm{m}^{2}\right)+\mathrm{BTC}+\text { Bio-control agent }+ \text { Nitrogenous Bio-fertilizer }+ \\
\text { Phosphatic Bio-fertilizer }\end{array}$ \\
\hline $\mathbf{T}_{16}$ & $\begin{array}{c}\mathrm{VC}\left(0.5 \mathrm{Kg} / \mathrm{m}^{2}\right)+\mathrm{CTC}+\text { Bio-control agent }+ \text { Nitrogenous Bio-fertilizer }+ \\
\text { Phosphatic Bio-fertilizer }\end{array}$ \\
\hline
\end{tabular}

Table.2 Effect of organic manures, bio-control agents and bio-fertilizers on plant growth and floral characteristic of gladiolus cv. American Beauty

\begin{tabular}{|c|c|c|c|c|c|c|c|c|c|c|}
\hline \multirow{2}{*}{$\begin{array}{l}\text { Treatment } \\
\text { (T) }\end{array}$} & \multicolumn{3}{|c|}{ Plant height } & \multicolumn{3}{|c|}{ No. of leaves/plant } & \multirow{2}{*}{$\begin{array}{c}\begin{array}{c}\text { FBI } \\
\text { (days) }\end{array} \\
\text { (a) }\end{array}$} & \multirow{2}{*}{$\begin{array}{c}\text { Spike } \\
\text { length } \\
\text { (cm) }\end{array}$} & \multirow{2}{*}{$\begin{array}{l}\text { No. of } \\
\text { florets/ } \\
\text { spike }\end{array}$} & \multirow{2}{*}{$\begin{array}{c}\text { Vase-life of } \\
\text { spike } \\
\text { (days) }\end{array}$} \\
\hline & $30 \mathrm{DAP}$ & $60 \mathrm{DAP}$ & 90 DAP & 30 DAP & 60 DAP & 90 DAP & & & & \\
\hline$T_{1}$ & 67.96 & 84.21 & 99.88 & 10.00 & 10.33 & 10.54 & 64.81 & 69.78 & 8.28 & 5.065 \\
\hline$T_{2}$ & 62.38 & 76.46 & 97.88 & 9.00 & 9.25 & 9.38 & 63.53 & 71.56 & 8.39 & 5.112 \\
\hline$T_{3}$ & 69.29 & 87.75 & 105.17 & 11.21 & 11.96 & 11.96 & 62.72 & 76.94 & 9.17 & 5.337 \\
\hline $\mathbf{T}_{4}$ & 69.35 & 88.92 & 105.50 & 11.04 & 12.13 & 12.21 & 63.03 & 80.56 & 9.72 & 5.347 \\
\hline$T_{5}$ & 70.33 & 89.42 & 112.13 & 11.25 & 11.46 & 11.54 & 63.50 & 82.28 & 11.39 & 6.445 \\
\hline$T_{6}$ & 70.63 & 93.96 & 110.00 & 11.50 & 11.79 & 12.17 & 62.42 & 84.28 & 12.00 & 6.550 \\
\hline$T_{7}$ & 73.21 & 97.04 & 116.00 & 12.63 & 12.25 & 12.29 & 63.14 & 88.11 & 12.11 & 6.767 \\
\hline $\mathbf{T}_{8}$ & 73.50 & 95.96 & 115.21 & 12.17 & 12.08 & 12.33 & 61.87 & 89.06 & 12.44 & 6.610 \\
\hline$T_{9}$ & 66.13 & 86.42 & 100.19 & 10.04 & 10.58 & 10.75 & 64.59 & 74.28 & 8.83 & 5.435 \\
\hline$T_{10}$ & 68.67 & 86.58 & 104.63 & 10.25 & 10.96 & 11.08 & 64.67 & 73.95 & 9.06 & 5.120 \\
\hline$T_{11}$ & 69.08 & 88.29 & 106.92 & 11.29 & 11.92 & 12.00 & 64.03 & 81.33 & 10.17 & 5.585 \\
\hline$T_{12}$ & 69.33 & 88.29 & 107.08 & 10.42 & 11.00 & 11.21 & 64.70 & 80.67 & 10.00 & 5.600 \\
\hline$T_{13}$ & 71.17 & 94.38 & 113.96 & 11.37 & 12.04 & 12.04 & 63.59 & 84.34 & 11.95 & 6.545 \\
\hline $\mathbf{T}_{14}$ & 71.67 & 94.21 & 113.81 & 11.54 & 11.33 & 11.38 & 64.42 & 87.67 & 10.22 & 6.585 \\
\hline$T_{15}$ & 74.46 & 98.79 & 127.19 & 12.92 & 13.87 & 14.04 & 60.48 & 93.06 & 13.39 & 6.900 \\
\hline$T_{16}$ & 73.79 & 98.46 & 116.21 & 12.79 & 13.58 & 13.79 & 61.70 & 90.44 & 12.67 & 6.800 \\
\hline $\operatorname{SEm}( \pm)$ & 1.260 & 1.423 & 1.775 & 0.703 & 0.588 & 0.585 & 0.592 & 2.035 & 0.491 & 0.308 \\
\hline $\mathrm{CD}(\mathrm{P}=0.05)$ & 3.564 & 4.025 & 5.128 & 1.989 & 1.663 & 1.655 & 1.675 & 5.757 & 1.389 & 0.871 \\
\hline
\end{tabular}


Table.3 Effect of organic manures, bio-control agents and bio-fertilizers on corm and biochemical quality parameters of gladiolus cv. American Beauty

\begin{tabular}{|c|c|c|c|c|c|c|c|}
\hline $\begin{array}{c}\text { Treatment } \\
(\mathbf{T})\end{array}$ & $\begin{array}{c}\text { Weight of } \\
\text { corm with } \\
\text { scale leaf } \\
(\mathbf{g m})\end{array}$ & $\begin{array}{c}\text { Weight of } \\
\text { corm after } \\
\text { dehusked } \\
\text { (gm) }\end{array}$ & $\begin{array}{c}\text { Diameter } \\
\text { of corm } \\
\text { (mm) }\end{array}$ & $\begin{array}{c}\text { Chlorophyll } \\
\text { content } \\
\text { (SPAD) }\end{array}$ & $\begin{array}{c}\text { Protein } \\
\text { Content } \\
\text { (mg/g of } \\
\text { fresh wt.) }\end{array}$ & $\begin{array}{c}\text { Phenol } \\
\text { (mg/g } \\
\text { fresh wt.) }\end{array}$ & $\begin{array}{c}\text { Anthocyanin } \\
\text { (mg/100g) }\end{array}$ \\
\hline $\mathbf{T}_{\mathbf{1}}$ & 53.81 & 52.73 & 61.91 & 61.34 & 4.79 & 0.47 & 180.80 \\
\hline $\mathbf{T}_{\mathbf{2}}$ & 52.21 & 50.41 & 61.23 & 61.32 & 3.96 & 0.42 & 176.67 \\
\hline $\mathbf{T}_{\mathbf{3}}$ & 65.91 & 61.36 & 64.79 & 66.03 & 6.37 & 0.56 & 189.07 \\
\hline $\mathbf{T}_{\mathbf{4}}$ & 62.66 & 62.16 & 63.21 & 64.18 & 6.44 & 0.62 & 186.90 \\
\hline $\mathbf{T}_{\mathbf{5}}$ & 63.48 & 59.78 & 65.83 & 65.32 & 6.35 & 0.55 & 193.92 \\
\hline $\mathbf{T}_{\mathbf{6}}$ & 62.33 & 59.65 & 64.66 & 64.99 & 6.28 & 0.61 & 194.87 \\
\hline $\mathbf{T}_{\mathbf{7}}$ & 68.83 & 66.85 & 66.08 & 66.03 & 6.69 & 0.80 & 206.28 \\
\hline $\mathbf{T}_{\mathbf{8}}$ & 69.40 & 67.53 & 66.62 & 66.27 & 6.74 & 0.83 & 203.42 \\
\hline $\mathbf{T}_{\mathbf{9}}$ & 58.50 & 55.60 & 63.00 & 62.52 & 4.28 & 0.50 & 192.57 \\
\hline $\mathbf{T}_{\mathbf{1 0}}$ & 58.23 & 57.08 & 62.54 & 63.18 & 4.98 & 0.53 & 177.21 \\
\hline $\mathbf{T}_{\mathbf{1 1}}$ & 64.34 & 63.82 & 64.49 & 62.29 & 6.29 & 0.55 & 198.53 \\
\hline $\mathbf{T}_{\mathbf{1 2}}$ & 65.72 & 63.24 & 64.47 & 63.84 & 6.23 & 0.66 & 198.67 \\
\hline $\mathbf{T}_{\mathbf{1 3}}$ & 67.87 & 65.77 & 65.79 & 65.96 & 6.26 & 0.58 & 199.97 \\
\hline $\mathbf{T}_{\mathbf{1 4}}$ & 68.28 & 66.33 & 63.37 & 65.99 & 5.81 & 0.72 & 203.05 \\
\hline $\mathbf{T}_{\mathbf{1 5}}$ & 72.34 & 70.57 & 69.16 & 67.07 & 7.20 & 0.96 & 214.17 \\
\hline $\mathbf{T}_{\mathbf{1 6}}$ & 72.25 & 69.87 & 68.30 & 66.49 & 6.86 & 0.83 & 206.54 \\
\hline $\mathbf{S E m}(\mathbf{m}$ & 2.012 & 2.056 & 0.935 & 0.887 & 0.289 & 0.010 & 5.249 \\
\hline $\mathbf{C D}(\mathbf{P = 0 . 0 5})$ & 5.811 & 5.938 & 2.645 & 2.509 & 0.818 & 0.028 & 14.849 \\
\hline
\end{tabular}

Highly significant total chlorophyll content as well as higher accumulation of various metabolites (reducing sugar, total phenol and amino nitrogen) might have resulted from enhanced plant growth and biomass production (Kohler et al., 2007). Use of PSB on the other hand rendered the phosphorus to be available to the plants leading to enhanced chlorophyll biosynthesis thereby improving many physiological processes like cell division, carbohydrate, fat and protein metabolism (Ali et al., 2014). Similar kind of results were noticed by Khalid et al., (2017) with the highest chlorophyll content upon inoculation with $A$. chroococcum, $B$. megaterium and $B$. mucilaginous bacterial strains and highest total phenol and flavonoid content upon inoculation with mycorrhizal fungi (Glomus fasciculatum) in spinach. Increased protein synthesis in $\mathrm{T}_{15}$ may be attributed due to increased availability and uptake of nitrogen, as nitrogen is the most important element in protein synthesis and its increase in optimum conditions increases the amount of protein (Rahmani et al., 2008). Anthocyanin is the major contributor of pigmentation in gladiolus flowers (Takemura et al., 2008). Anthocyanin biosynthesis took place from anthocyanidin by addition of sugars. Plant Growth Promoting Rhizobacteria influences the anthocyanin formation in plants (Rodriguez et al., 2014). Application of Azotobacter and PSB enhanced the anthocyanin formation (Selvarathi et al., 2010) in tomato.

The present investigation revealed that the treatment " $\mathrm{T}_{15}$ "comprised of Vermicompost $\left(0.5 \mathrm{Kg} / \mathrm{m}^{2}\right)+$ Bio-inoculant treated corm + Bio-control agent (a mixture of Pseudomonas fluorescens + Trichoderma @ $0.5 \mathrm{Kg} / \mathrm{m}^{2}$ each)+ Nitrogenous Bio-fertilizer(a mixture of Azotobacter + Azospirilum@ $0.5 \mathrm{Kg} / \mathrm{m}^{2}$ each)+ Phosphatic Bio-fertilizer(Phosphate solubilizing bacteria @ $0.5 \mathrm{Kg} / \mathrm{m}^{2}$ ) showed significant increase in the growth, flowering 
and quality parameters of gladiolus $\mathrm{cv}$. American Beauty as compared to other treatments. Hence, $\mathrm{T}_{15}$ may be considered as best organically nutrient supplementation in the package of practices for organic production of gladiolus in the Terai region of West Bengal.

\section{Acknowledgements}

The authors are grateful to the Department of Science and Technology, Ministry of Science and Technology, Government of India for providing financial support through the INSPIRE Fellowship in successfully carrying out the Ph.D. research work.

\section{References}

Ali, A., Mehmood, T., Hussain, R., Bashir, A., Raza, S., Najam-ud-Din and Ahmad, A. 2014. Investigation of biofertilizers influence on vegetative growth, flower quality, bulb yield and nutrient uptake in gladiolus (Gladiolus grandiflorus L.). Int. J. Pl. An and Env. Sci., 4(1): 95-99.

Cordenunsi, B.R., Nascimento, J.R.O. and Lajolo, F.M. 2003. Physico-chemical changes related to quality of five strawberry fruit cultivars during coolstorage. Food Chemistry, 83: 167-173.

Devi, G.B.,Potdukhe, S.R. and Guldekar, D.D. 2017. Biological control of wilt of gladiolus caused by Fusarium oxysporum f. sp. Gladioli. J. Soils and Crops,27(1): 84-87.

Dubey, R.K., Misra, R.L., Singh, S.K. and Manisha. 2010. Efficacy of biofertilizers and chemical fertilizers on certain floral qualities of gladiolus. Indian J. Hort., 67: 382-385.

Khalid, M., Hassani, D., Bilal, M., Asad, F. and Huang, D. 2017. Influence of biofertilizer containing beneficial fungi and rhizospheric bacteria on health promoting compounds and antioxidant activity of Spinacia oleraceaL. Bot. Stud., 58:35.
Kohler, J., Caravaca, F., Carrasco, L. and Rolden, A. 2007. Interactions between a plant growth-promoting rhizobacterium, an AM fungus and phosphatesolublizing fungus in the rhizosphere of Lactuca sativa. Appl. Soil Ecol., 35: 480-487.

Kumar, R., Kumar, R. and Kumar, P. 2011. Effect of integrated use of chemical fertilizers, biofertilizers and biostimulants in gladiolus (Gladiolus grandiflorus L.) cv. Sancerre. Progressive Horticulture, 43(1): 149152.

Kumar, S., Singh, R.N., Choudhary, V.P. and Neeraj. 2017. Effect of integrated nutrient management on growth and yield of tomato in Begusarai district of Bihar. Indian J. Hort., 74(4): 541-545.

Kuotsu, N.R., Keditsu, R. and Hemanta, L. 2018. Response of organic and inorganic nutrient sources on the growth and flowering of Gladiolus primulinus cv. Candyman. Int. J. Curr. Microbiol. App. Sci., 7(05): 2537-2547.

Lowry, O.H., Rosenbrough, N.H., Farr, A.L. and Randall, R.J. 1951. Protein measurements with folin phenol reagent. J. Biol. Chem., 193: 265-275.

Malick, C.P. and Singh, M.B. 1980. Plant Enzymology and Histo Enzymology, Kalyani Publishers, New Delhi, pp. 286.

Naznin, A., Hossain, M.M., Ara, K.A., Hoque, A., Islam, M. and Hasan, T. 2015. Influence of organic amendments and bio-control agent on yield and quality of tuberose. J Horticulture, 2: 156.

Pandey, A., Singh, A.K. and Sisodia, A. 2013. Effect of vermicompost and bio-control agents on growth and flowering of gladiolus cv.J.V. Gold. TAJH, 8(1): 4649.

Pansuriya, P.B., Varu, D.K., and Viradia, R.R. 2018. Effect of biostimulants and biofertilizers on growth, flowering and quality of gladiolus (Gladiolus grandiflorus L.) $\mathrm{Cv}$. American beauty under greenhouse conditions. Int. J. Chem. Stud., 6(2): 2191-2196. 
Pati, R. and Mukhopadhyay, D. 2008. Inorganic phosphorus fractions in some acid soils under terai situations of West Bengal. Research on Crops,9(1): 57-60.

Rahmani, N., Valadbighi, S.A., Daneshian, J., Bidgholi, V.M. 2008. Effect of different levels of drought stress and nitrogen on oil yield in evergreen herb (Calendula officinalis L.). J. Res. Arom. Plant Iran., 24(1): 101-108.

Rodriguez, R.Z., Matson, M.V.C., Montiel, L.G.H., Amador, B.M., Puente, E.R. and Lara, L. 2014. Effect of Pseudomonas putida on growth and anthocyanin pigment in two poinsettia (Euphorbia pulcherrima) Cultivars. Sci. World J., pp. 1-6.

Sathyanarayana, E., Patil, S., Bahubali, M. and Chawla, S.L. 2018. Effect of INM on gladiolus (Gladiolus grandiflorus L.) cv. American Beauty under Navsari and TansaConditions. Int. J. Pure App. Biosci., 6(4): 48-55.

Sathyanarayana, E., Patil, S., Chawla, S.L.and Patel, D.K. 2017. Influence of integrated nutrient management on gladiolus (Gladiolus Grandiflorus L.) cv. American Beauty. Int. J. Curr. Microbiol. App. Sci., 6(8): 379-386.

Selvarathi, P., Ramasubramanian, V. and Jeyaprakash, R. 2010. Bioremedial effect of Azotobacter and Phosphobacterium on the growth and biochemical characteristics of paper mill effluent treated Lycopersicum esculentum Mill. Journal of Biological Science and Research, 1(1): 58-64.

Sharma, N. and Singhvi, R. 2017. Effects of chemical fertilizers and pesticides on human health and environment: A Review. Int. $j$. agric. environ. biotechnol., 10(6): 675-679.

Singh, S., Singh, B.K., Yadav, S.M. and Gupta, A.K. 2014. Potential of biofertilizers in crop production in Indian Agriculture. American Journal of Plant Nutrition and Fertilization Technology, 4: 33-40.

Sisodia, A. and Singh, A.K. 2015. Effects of farmyard manure, vermicompost and Trichoderma on flowering and corm attributes in gladiolus. Bangladesh $J$. Bot., 44(2): 309-314.

Srivastava, R., Preetham, S.P. and Chand, S. 2014. Effect of organic manures and biofertilizers on vegetative, floral and post-harvest attributes in tuberose (Polianthestuberosa) var. Shringar. Asian Journal of Biological and Life Sciences, 3(1): 6-9.

Takemura, T., Takatsu, Y., Kasumi, M., Marubashi, W. and Iwashina, T. 2008. Anthocyanins of gladiolus cultivars and their contribution to flower colors. $J J P N$ SOC HORTIC SCI., 77(1): 80-87.

Thakur, N., Kumar, P. and Singh, S.K. 2016. Conjunct use of organic manures, biofertilizers and inorganic fertilizers for improving plant health of plum cv. Santa Rosa. Indian J. Hort.,73(2): 188-191.

\section{How to cite this article:}

Khwairakpam Lily Devi, Soumen Maitra and Bhattacharya, P. M. 2019. Combined Efficacy of Organic Manures, Bio-Control Agents and Bio-Fertilizers in Improving Growth, Flowering and Quality Parameters of Gladiolus Cv. American Beauty. Int.J.Curr.Microbiol.App.Sci. 8(10): 1792-1800. doi: https://doi.org/10.20546/ijcmas.2019.810.208 